\title{
VIRTUES AND CONSEQUENCES IN TEACHING ETHICS ${ }^{1}$
}

\author{
GABRIELA PLATKOVÁ OLEJÁROVÁ
}

\begin{abstract}
Teacher training occupies an important place in the theory of professional ethics, so long as education is understood to mean the intentional moral shaping of pupils' actions and behaviour. It is important that training on the theory of teaching ethics and teaching practice enhances teachers' professional morals. The main aim of this paper is to explore and analyse the professional ethics of the teacher, concentrating on aspects of decision-making, action-taking and behaviour from the viewpoint of the Ethics of Social Consequences. The importance of the teacher's character and virtues also receive attention. The author suggests that the teacher's character influences the decisions teachers make, and that the virtuous actions/ virtue-based actions and behaviour of the teacher should produce positive social consequences and conform to the values of humanity and human dignity.
\end{abstract}

Key words: teaching ethics; virtues; character; consequences; ethics of social consequences.

\section{Introduction}

In general, the notion of the good teacher is one of a professional with a broad range of professional competences and the knowledge considered necessary for good teaching practice obtained at university. Moreover the general public expect good teachers to hold certain morals and virtues that will guide them to act appropriately in line with the values of teaching ethics. The professional and personal actions and behaviour of the teacher have a fundamental impact on the quality of pupil life in the classroom as well as on the formation of the pupil's character. The professional decisions teachers make relate to their ethical duties concerning the pupils, development of character and fostering of good behavior and actions for future personal and professional life. Situations and problems occurring between teachers and pupils in pursuit of this goal call for good solutions. It is therefore essential that teachers receive continuous training relating to their profession and to ethics, and to ethical and moral problems arising during teaching. Future teachers should receive instruction on the ethics of teaching so they can better consider the ethical and moral dimensions of

1 This article is part of the VEGA 1/0629/15 Ethics of Social Consequences in the Context of Contemporary Ethical Theories project.

DE GRUYTER 
teaching and reflect appropriately on moral problems and act accordingly with positive consequences for pupil moral development. In this paper, the importance of instruction on the professional ethics of the teacher is explored, looking at its impact on the teacher's moral thinking, decisions and actions as well as the effects it has on enhancing the virtues and character of the teacher. Teachers should act in line with the essential values of the ethics of teaching, i.e. the values of humanity and human dignity, and consider positive social consequences over negative ones.

The main aim of this paper is to analyse the professional ethics of the teacher, concentrating on aspects of decision-making, action-taking and behaviour in relation to the Ethics of Social Consequences. The Ethics of Social Consequences is a weak non-utilitarian consequentialism theory developed by Vasil Gluchman. The actions and behaviour of moral subjects are evaluated on the bases of the consequences of their decisions, actions and behaviour, and positive social consequences should prevail over negative ones (they should not be maximized). Humanity, human dignity, moral right, justice, responsibility and tolerance are the essential values of this theory (Gluchman, 1997, 2008). The theoretical and methodological approach used in this article is justified as follows:

a) Every action results in certain consequences which should be taken into consideration when the action is being evaluated (in contrast to deontological ethics) because these consequences affect the lives of others. The actions and behaviour of teachers should be viewed through the consequences of their decisions, actions and behaviour because teachers' professional and (im)moral decisions, actions and behaviour have a significant impact on the quality of pupil life in the classroom.

b) In the Ethics of Social Consequences the moral subject's motivation and intentions and resulting consequences are important when evaluating the action overall. The motivation and intentions of teachers are very important where various external factors (influencing ethically conflicting situations) are concerned and sometimes the overall outcome of the decision.

c) The moral subject's position regarding the achievement of positive social consequences - in the Ethics of Social Consequences it is essential that these prevail (and are not maximised as in utilitarianism). One cannot expect teachers to deliver the best possible consequences for the quality of pupil life in the classroom given the number and heterogeneity (age and cognitive, social, emotional, educational and moral characteristics) of the pupils in the classroom, as well as their ability to accept and view the professional decisions of the teacher. The same decision can produce different reactions in pupils. Therefore it is unrealistic to expect teachers to deliver the maximum positive social consequences as a result of their actions. However, we can expect teachers to seek to ensure positive social consequences prevail over negative ones.

d) In the Ethics of Social Consequences the evaluation of the subject's action and behaviour is performed in relation to the situation, context and circumstances (unlike moral duty or rule adherence in deontological ethics). Often, teachers' actions will depend on the situation and will not fully conform to a norm or a value; however, teachers will be able to justify or explain this in relation to the situation. By following the Ethics of Social Consequences, a situational approach and flexible solutions can used to deal with problems in the classroom. 
e) The Ethics of Social Consequences is based on the values of humanity, human dignity, moral right, justice, tolerance and responsibility. These are the primary values in the ethics of teaching and are important in the teacher's professional and moral decisions, actions and behaviour, which are performed out of a moral duty to protect, support and enhance (value of) the life of the pupil. When performing these the positive social consequence should prevail over negative ones.

In this paper, I aim to examine the decisions, actions and behaviour of the teacher from the Ethics of Social Consequences perspective. The focus is on the importance of teachers' moral thinking, enhancement of character and the development and reinforcement of virtues. I am of the opinion that these factors affect the appropriation of teachers' decisions which should be in keeping with the values of humanity and human dignity and lead to positive social consequences prevailing over negative ones. ${ }^{2}$

\section{Importance of training teachers in the theory of professional ethics}

Elizabeth Campbell points out that teacher training programmes do not adequately cover the ethical and moral aspects of teaching, and the language of ethics (of teaching) used in discussion and argumentation. Where professional ethics does feature as part of the programme, then it is only superficially in the form of codes of ethics or policy and legal norms. I think that the importance of the ethics of teaching and the relevance of teaching morals should be more strongly promoted and encouraged in teacher training programmes. Campbell is critical of the overemphasis of the pedagogical, social and cultural aspects at the expense of the ethical and moral aspects. She believes the value of the teacher should be viewed through the moral cultivation of the teacher and that of others, and that the teacher's moral character, characteristics and awareness of moral responsibility are all important as well (Campbell, 2013, pp. 415-41).

University teacher training on the theory of the professional ethics of the teacher is essential because it highlights the ethical aspects of the everyday practices of the teacher in the classroom. Moreover trainee teachers should also be taught to look out for the potential ethical and moral problems which are part of their profession and view them in the context of the criteria of morality in ethical theories, specifically in light of the values of the ethics of teaching and the desired virtues of the teacher.

Courses on the theory of the ethics of teaching provide us with an essential framework for teacher motivation and the intention to act appropriately in every situation, emphasising the quality of pupil life in the classroom ${ }^{3}$ and the consequences of the teacher's thinking,

\footnotetext{
2 This ethics theory should not be seen as superior to the other theories because all ethical theories are the bearers of authentic values. It was selected because of its value preferences relating to the environment, upbringing and education. This is not to reject other ethical theories or their use in the teaching of ethics; I tolerate pluralism of ethical theories and different moral approaches arising from any distinctive original theory.

3 I understand quality of pupil life in schools to mean the health, psychological and social development of pupils as well as their self and mental development. It is not easy to define quality of life as it is a multidimensional concept. In this paper, it is understood to be a feeling of overall subjective satisfaction, pupil wellbeing and pupils' subjective perception of their place in the social
} 
decisions and actions. Teachers act and behave responsibly when aware of their personal influence on the pupil. The fact that teachers have an intentional (and unintentional) professional and personal influence on their students increases their responsibility for the pupil's personal, social, emotional and moral development and indicates the importance of teaching the values of ethics, such as respect, reverence, trust, honesty, cooperation, student wellbeing (physical, mental and spiritual), empathy, equality, etc. It also points to the importance of virtuous actions-actions which are humane, just, responsible, honest, brave, patient, protective, kind, dignified, truthful and respectful.

Educating teachers about professional ethics in the context of the quality of pupil life in the classroom, focuses attention on the qualitative (moral) aspects of education especially the teacher's ability to create and promote a positive moral and social atmosphere in the classroom; on forming relationships with pupils and fostering pupil-pupil relationships based on mutual trust, respect and cooperation; on encouraging open and honest dialogue (without fear or coercion); on developing and assessing pupils' personalities at both the cognitive and emotional levels; on providing a positive personal role-model; on engaging with pupils in relation to their interests; on respecting and fostering the values of respect, dignity, humanity and justice; on protecting and reinforcing pupils' rights; on assessing pupils professionally and with empathy; on identifying and solving pupils' educational problems; on providing pupils with the opportunity of expressing their ideas, attitudes or feelings; on supporting and encouraging them; on giving them positive feedback and on helping them build self-confidence and self-respect.

Roffey analyses pupil wellbeing, which is indicated by satisfaction with life at school and with school obligations and duties as well as positive social-emotional behaviour. The optimal wellbeing of a pupil is predominantly characterized by positive feelings and attitudes, a positive relation to school, resistance or a high level of learning satisfaction. Roffey also reiterates that everything that happens at school has an impact on selfconfidence, self-assurance, positive assessment and motivation. It is important to create good, positive relations with others and strive for a positive working environment to foster a positive feeling of wellbeing in the pupil (and teacher) (Roffey, 2012, pp. 8-10).

The fact that teacher actions, behaviours and characteristics that promote pupil quality of life in the classroom indicates that the emphasis is on the teacher's character and the influence he or she has on pupils in the classroom. This influence is dual-pronged. Firstly, the teacher is a potential role-model for pupils. The teacher is a moral model and can expect the public and parents to have specific demands and expectations which have to be dealt with ${ }^{4}$. If teachers are aware they act as role-models, this encourages them to adopt a

context of the classroom. Pupils receive an education and this may be a component in the positive development of the pupil in keeping with his or her potential and capabilities (Lukášová, 2010, pp. 43-82). Teachers have a professional and personal influence on pupils, affect the quality of pupil life in the classroom and are responsible for enhancing the various components that make up pupil quality of life. Hence teachers should acknowledge how their actions may impact on the pupil and be capable of thinking about the consequences of their actions and behaviour.

${ }^{4}$ Since teachers act as role-models, they should hold and promote the values that pupils are expected to follow. Regarding teacher influence on pupils, it is not enough just to explain what responsibility or tolerance is; it is much more important to demonstrate these values in practice. This way the teacher 
responsible approach towards themselves and to (self) reflect upon decisions, actions and behaviour, which is necessary for them to be able to assess and evaluate the consequences of their actions and their influence on the quality of pupil life in the classroom. Thus, the teacher's morals are primarily relevant since the teacher acts as role-model point and the morals are expressed in the teacher's behaviour and actions. The teacher should be asking How should I behave? How should I act?-and in seeking the answer reflect upon the necessary personal morality and professional morals. Angela Lumpkin asks, what kind of a role model is the teacher? She suggests that teacher integrity is essential and that this entails consistently doing what is right, even when it is easier to do something that is personally more beneficial (Lumpkin, 2008, p. 40). Pupils will be aware of teacher integrity. Pupils base their assessments of the character of their teachers on the way they themselves are treated and taught. Lumpkin emphasises that teachers can serve as role models by teaching character and the moral virtues of honesty, trust, fairness, respect and responsibility. Teachers with character serve as role models by telling the truth, respecting others, accepting and fulfilling responsibilities, playing fair, earning and returning trust and living a moral life. Moreover teachers can play an essential role in helping pupils to learn and use moral-reasoning (Lumpkin, 2008, pp. 47-49). Others describe teachers as role models using the concept of the ethical person. This entails justice, objective assessment, equal treatment of pupils and showing respect, as well as pupil expectations that they will not be judged by their looks, behaviour or social background. Honesty and trustworthiness are also important (Läänemets, Kalamees-Ruubel, \& Sepp, 2012, pp. 27-31).

Secondly, a teacher exerts influence through the act of teaching, which is informed by professional competencies and skills acquired mainly through university study; however, improvement is dependent on continuous professional development and experience. The enhancement of professional skills is associated with awareness of educational "elusiveness" and to the impossibility of being completely prepared for teaching and its inherent problems.

I agree with Žilínek that teachers should work on professional and moral selfimprovement because personality, potential and competencies are key to teaching (Žilínek, 1997, p. 193). Teachers do not only educate, but also help pupils to become responsible good people. Hence teachers should not forget their role involves not only professional competences but also ethical behaviour models. Viera Bilasová suggests that university teacher education plays an important role in the cultivation of ethics in the school environment. Teacher training should be of good quality and cover methodological and teaching competences, taking account not only of the abilities and skills required for that particular area but also focusing on a human approach (Bilasová, 2016, pp. 24-25). This bring us to the teacher's personality and the moral skills or virtues which the teacher should seek to consciously improve and develop through training and self-improvement in moral thinking, decision-making and performance through adopting targeted and responsible solutions to everyday teaching issues. According to Elen Seghedin, everyday life in the classroom is imbued with moral significance through mutual interpersonal relationships

helps pupils to become highly principled and exerts a positive influence on the pupil's socio-moral development (Klembarová, 2015, pp. 80-81). 
and contacts. Thus, the moral values of the teaching profession are not norm-based but are created and formed through everyday praxis and experience. This is the point at which a teacher's professional morals begin to develop. Therefore Seghedin suggests university lecturers should create ethical and moral situations and dilemmas in which teachers and pupils can reflect on how to be morally reflective and autonomous (Seghedin, 2014, p. 16). Moral reasoning can be enhanced through identifying ethical obstacles, analysing negative examples from the classroom, teaching ethical terms and theories, holding open (and critical) discussions and encouraging reflection and self-reflection (Clark, 1995, in Colnerud, 2006, p. 371).

This is why teacher trainees should be taught the theory of teaching ethics, which is about acquiring and improving ethical competencies so future teachers can identity the problematic ethical and moral aspects of teaching in teacher-pupil, pupil-pupil, co-teacher or teacher-parent relationships. Teaching professional ethics should also provide future teachers with the practical competences and skills to help them adequately solve ethical problems in teaching. This aspect of university-based teacher training is also suggested by Bilasová, who highlights the importance of theory in quality university-based teacher training (understanding ethical theories, the ability to think ethically, reason, argue and to apply knowledge to develop practical moral solutions) and the ability of trainee teachers to apply the theory in practice and develop the competency to analyse real moral problems in various areas and spheres of life (Bilasová, 2014, pp. 10-11). Teachers should be capable of using moral practices and ethical theories to make good decisions-decision that will be benefit the student and quality of life in the classroom. Hence in professional ethics, the focus should not just be on learning professional values and norms ${ }^{5}$ but on improving the teacher's moral thinking and reflecting responsibly on current ethical and moral problems in educational practice. University courses on professional ethics require teacher trainees to master the theory and the ability to think, decide and act morally and learn to identify and solve ethical and moral problems in schools.

Educating trainee teachers on the theory of professional ethics is important since they have to acknowledge the moral dimension of teaching and accept and welcome it, since it is key to incorporating teaching ethics into practice and it has an impact on pupil quality of life. Future teachers play a major part in this process of acknowledgement. Whether or not acknowledgement occurs depends on the moral development of the teacher trainee, which informs their ability to distinguish between good and wrong, to make free decisions and actions and justify them, whether in line with the accepted ethical and moral values of that

\footnotetext{
5 Gunel Colnerud highlights the importance of ethical norms in the teaching profession for three reasons. The first one relates to the fact that some moral problems are complex and require more deliberation. The second is that people's interests and egoism may influence their moral judgement. Finally the third reason concerns inadequacies in moral reasoning (not every teacher is capable of sufficient moral reasoning). According to Colnerud, the virtues and norms of the teaching profession are compatible rather than exclusive. The pupil-teacher relationship is shaped by inequality, dependency and involuntariness and so pupils are exposed to the moral judgement of the teacher (which may not always be adequate). The teacher has to make sure that the relationship is beneficial for the pupil, otherwise the consequences for the pupil's wellbeing may be serious and this is why teachers should be familiar with the profession's ethical norms and rules (Colnerud, 2006, p. 372).
} 
society or not. The emphasis on the values of the teaching profession alerts future teachers to the professional moral actions and behaviour expected of teachers, to the limits within which their actions are assessed by the public and parents and to what is considered to be good/bad professional conduct. Trainee teachers who have been taught the ethics of teaching can reflect on their awareness of the responsibilities associated with their professional moral decisions, actions and behaviour, and consider their personal predispositions for the profession, their skills and willingness to improve and build on their character and moral abilities, virtues, attitudes and relationships. ${ }^{6}$

\section{Virtues and consequences in the moral actions of a teacher}

In this paper, the ethical dimension of teaching is considered in relation to the teacher's personality and character, virtues and ability to think morally, make decisions and act. Hence knowing the virtues (cognitive dimension-the teacher's ethical knowledge, ethical reflection) a teacher should have and how to develop them (the practical and moral dimension) is essential to the professional morals of the teacher and is an important area of research. However, it has to be noted that simply acquiring the theoretical knowledge relating to teacher personality and virtues does not guarantee that the teacher will always act in a just, good, humane, compassionate, respectful, and so forth, way. Teachers do not always know which action will prove to be just and appropriate, especially when under pressure. Nevertheless, the theoretical knowledge acquired at university may motivate future teachers into avoiding being intentionally unjust and encourage them to identify and recognize which situations (and their moral aspects) require a fair approach (Campbell, 2013, pp. 423-424).

Although teachers may have adequate professional and ethical knowledge and the required competencies - acquired through instruction on the theory of the professional ethics of the teacher-they will make mistakes in moral thinking and when solving moral

\footnotetext{
6 There are other ways in which teacher training on the professional ethics of the teacher is important. Júlia Klembarová points out the importance of the professional ethics of the teacher in relation to special needs education. Various situations can arise in the everyday contact between teachers and special needs pupils where teachers have to make decisions about their actions whilst ensuring pupil welfare is uppermost. I think it is crucial to have a knowledge of the ethics, ethical principles, norms and borderlines that should not be crossed. Special needs pupils are frequently more vulnerable than other pupils and more teacher-dependent. Since they represent a specific group (given their special needs) specific situations and problems will arise requiring special and morally acceptable solutions (Klembarová, 2012, p. 156). Marta Gluchmanová highlights the importance of the professional ethics of the teacher in relation to the growing violence and aggressive behaviour in schools. She argues that teachers should minimize aggressive pupil behaviour as it may impact on the health and/or lives of other students in the classroom and result in a degradation of the dignity of the victim and affect the victim's self-confidence. It may also disrupt the teacher's work and pupil learning. Gluchmanová believes that the teacher should strive to form a reasonable partnership based on mutual efforts to understand the pupils and their behaviours or actions. At the same time, a desirable atmosphere should be created and conditions put in place so pupils are able to understand the teacher's role and position in the relationship, including his or her moral duty and responsibility for pupil moral development, which is aimed at helping them become mature moral agents (Gluchmanová, 2012, p. 93).
} 
problems with negative consequences for pupil quality of life in the classroom. Mistakes also happen because the teacher is not capable of linking the ethical theory to practice when solving practical ethical and moral problems. Mistakes may also result because of a reduced individual capacity to detect the ethical and moral dimension of problems in the classroom. Other aspects that contribute to error-making are low subjective ambition, lack of will and persistence in dealing adequately with problems (motivation and aim) and lack of ambition to cultivate teaching virtues and strive for good actions. Kuře claims that desirable actions can be achieved by fostering professional character and the ambition to achieve such actions (Kuře, 2009, pp. 39-56).

I think the character of the teacher has an important influence on moral decisions and actions because although teachers may have knowledge of the ethical and moral values of the teaching profession and the consequences of pursuing them, they may not in fact act in accordance with these values if they do not have the character or desirable dispositions. In other words, teachers may have received instruction on the theory of professional ethics but if they lack the character and desired virtues and are unable to recognize what is good and to think morally, they will not be applying that knowledge or promoting the teaching of values and virtues and they will not be striving to act appropriately when solving moral problems in teaching.

Improving the character of teachers and their ability to think morally and reflect on everyday classroom situations is essential because the professional decisions and actions of the teacher include an ethical obligation towards the pupils and are related to improving pupil quality of life. The ethical obligation of teachers towards themselves, in terms of professional and moral (self) reflection, has, as has been mentioned, a dual impact on teacher and pupil alike. Therefore the emphasis is on improving the teacher's character, positive moral features and virtues through experience. Teaching practice is a rich ethical source of moral dilemmas and situations and in solving these, the teacher is trained to take virtuous actions and learn to notice and identify what is going and differentiate between right and wrong, and good and bad. Developing competence in practical prudence (using the right solutions in teaching) and wisdom (theory learned at university) has a positive effect on the teacher's virtues and character. Zuzana Danišková has explored the Aristotelian link between theoria and praxis in university-based teacher education. She believes that teachers are professionals who, in addition to knowing the theory (increases professionalism) of teaching, are also able to reflect on classroom situations and are able to continuously assess their performance, which improves the quality of teaching in the classroom (Danišková, 2014, pp. 194-195). The teacher's ability to handle a (problematic) teaching situation reflects the way in which professional teaching experience meets theoretical knowledge, and how this ultimately leads to the acquisition of more knowledge (through experience).

Virtues, the ability to think morally, make decisions and act are factors which should ensure that teachers' actions and behaviour have positive social consequences and that there is harmony between professional decision-making and the basic values of the ethics of teaching - humanity, human dignity and moral right (justice, responsibility and tolerance). A highly-principled teacher will have knowledge of the ethical and moral values of teaching ethics and will attempt to ensure they enhance decision-making, actions and behaviour, while avoiding or preventing actions that run contrary to these values. Pupil quality of life 
in the classroom is shaped by the teacher taking moral decisions and acting and behaving in accordance with the values of teaching ethics, and the teacher's character, moral features and virtues have an impact on this. The focus here is on the teacher's personality and character because it is impossible to discuss good and right moral actions in the teaching profession without reference to the persona or personality of the teacher and all the associated features, virtues, thinking and actions they influence. Actions cannot be assessed on the basis of consequences alone; the person, character, motivation and intentions all have to be taken into account.

What is the relationship between the teacher's character, virtuous actions, ability to think morally, make decisions and act so positive social consequences prevail over negative ones? I am suggesting that it could be based upon the values of teaching ethics in the context of improving pupil quality of life improvement, i.e. the values of humanity and human dignity, which are essential to the Ethics of Social Consequences. I am also highlighting the fact that the teacher's character and ability to think morally may be additional criteria for morality in the Ethics of Social Consequences.

Gluchmanová's work (2008, 2009a, 2009b) is concerned with applying the values found in the Ethics of Social Consequences in teaching. In adhering to values, the emphasis is on the value of humanity, which means those actions taken by the teacher to support, protect, educate and cultivate students as well as help them with everyday problems and act so as to produce positive social consequences. The value of humanity is a moral surplus value because in their jobs teachers help strangers (not close friends, family or acquaintances) and thus a higher quality of relationship is created through actions and behaviour. This is the formulation of a new value framework which is entirely appropriate to teaching because it concerns something that is intrinsic to the teaching profession-helping others. Teachers who follow this humanity as a moral surplus value approach have to perform actions that support and protect human life (that of children and young people) as well as actions that produce positive social consequences. Teachers should help others and educate and cultivate in addition to fostering moral development. Enforcing the value of humanity also requires teachers to minimize fear and threats (fighting, bullying, pain, mutual hurt, infringement of rights) in the classroom and ensure that all are treated as equal partners (no pupil exploitation, no infringement of children's rights). Teachers pursue both passive (expressing acknowledgement, understanding, sympathy and offering support) and active forms of humanity (assistance, cooperation in solving practical problems) (Gluchmanová, 2009b, pp. 88-94).

Human dignity is the ability of a person to perceive the value of all other people, regardless of gender, race, world-view or religion, as equals. Dignity also refers to the ability to reflect on one's personal and moral qualities and the self-respect of the person based on an acknowledgement of their moral qualities and abilities (Gluchman, 1999, p. 65). Human dignity is not an eternal and immutable constant that is always valid and has the same value regardless of the actions of the human being. It is variable and the human dignity of a person is not revered simply on the basis of human existence (Gluchman, 2005, p. 148). ${ }^{7}$

7 So long as the consequences are the moral criteria of an action, human dignity will grow on the basis 
In teaching, the value of dignity is expressed through mutual reverence and respect for pupils (regardless of age, gender, religion, race, political alliance, national or social background) and is aimed at enhancing the human personality, respect for human rights and at facilitating mutual understanding, tolerance and friendship (no bullying, punishment or abuse for being different) (Gluchmanová, 2009b, pp. 97-100). According to Gluchmanová, the teacher also has a duty to behave and act in such a way that the human dignity of those in a teaching situation is respected and the infringement of human dignity of any human being is prevented. All teachers should also foster human dignity in relationships with pupils' parents as well. Teachers should view parents as partners when solving issues and problems at school. Teachers should always behave respectfully towards parents regardless of their social status, for example, and vice versa (Gluchmanová, 2009, pp. 101-103).

Expressing humanity and human dignity in relation to pupil quality of life means helping and supporting all students, making no distinctions in relation to the social context of the classroom and striving for the positive development of pupils in line with their potential and capabilities, including moral development.

When pursing the values of humanity and human dignity, teachers' actions should demonstrate the following virtues: empathy, patience, care, wisdom, trustworthiness, solidarity, justice, respect, honesty, kindness, modesty, carefulness, etc. All teachers should cultivate these virtues in order to be virtuous. These virtues can be acquired by trainee teachers through the study of the professional ethics of the teacher, which may also involve the study of different ethical theories and methods of assessing a teacher's actions and behaviours. However as Viera Bilasová and Viera Žemberová point out, teachers must make an effort to familiarise themselves with the virtues before they can act virtuously (Bilasová \& Žemberová, 2005, p. 24). Hence studying the theory of professional ethics is important not only to gaining an understanding of teachers' virtues but so teachers are able to recognize what is moral and to ensure this informs their approaches to problem solving; it is important to the teacher's ability to decide and act virtuously.

As mentioned above, despite having received teacher training and holding good professional competencies, teachers often have low subjective aspirations and lack the will and persistence to handle problems appropriately. They may also lack sufficient ambition to cultivate teaching virtues and to strive for good actions. At the same time, they intentionally fail to improve their skills in identifying the ethical and moral dimensions of teaching. So although teachers may be familiar with the ethical and moral values of the ethics of teaching, they may not act in accordance with them simply because they forgot to consider the ethical dimensions of teaching and their consequences when preparing for the lesson or because they do not view it as being important to effective teaching and to encouraging good teacherpupil relations. Instead they may focus on the professional and cognitive aspects of teaching far more than on the ethical and moral ones. We can differentiate between those who intentionally do not follow professional ethical and moral values and those who do not act

of the person's actions. Thus human dignity has two levels. The first one is based on the acceptance of dignity as the value attributed to every human being because they are morally equal. The second meaning of dignity relates to the actions of the person. Actions that have positive social consequences enhance a person's dignity (mathematically speaking, it moves from zero upwards). 
virtuously on the one hand and those who intentionally do not follow professional ethical and moral values but are able to justify this rationally on the other; for example they may justify it on the grounds that doing so led to positive consequences.

Teachers who intentionally fail to adhere to the values of humanity and human dignity in the classroom may, as mentioned above, lack character, and so in this case studying the ethics of teaching, learning about the ethical and moral values of the teaching profession and the virtues of the teaching profession and the obligation to accept these values and virtues is no guarantee that they will put these into practice.

The teacher's character is particularly important in decision-making and performance because a highly principled and virtuous teacher will act in accordance with the values of the professional ethics of the teacher (without being ordered to so or out of external motivation, but out of a conscious decision). A highly principled teacher may fail to adhere to certain values but only where the focus is on the positive consequences of doing so. Hence, the highly principled teacher is able to think morally and assess the ethical and moral aspects of the situation before coming to a decision.

For example, an elementary school teacher has arranged a meeting with a pupils' father. She has never met him before because all previous problems have been solved via the telephone. This time she wants to see the father in person to discuss the behaviour of his son, John, who was involved in a fight in the classroom that he started. The father enters the teacher's office with a belt in his hand, furious and requests to see his son. The teacher tries to explain that she did not call him so he could beat his son. But the father says that the belt will solve everything. After hearing this, the teacher tells the father that John did not start the fight, the others did and that she was just concerned for his wellbeing and how he would get home as the other boys might wait for him after school. Later on, the teacher is troubled that she did not tell the truth. She lied to spare John a beating. What good would telling the truth have done? Was the teacher right to lie to the father? (Gluchmanová \& Gluchman, 2008, pp. 209-210).

If we consider this using the Ethics of Social Consequences morality criteria, the teacher's action, not telling the truth to the father, who is aggressive, because doing so would only have caused more aggression and ended in him physically punishing his son, then the decision was right. Although she failed to follow the values of teaching ethics, e.g. the values of justice, honesty and truthfulness, at that particular moment the teacher was able to identify the moral aspects of the situation and by practising moral thinking (practical wisdom) arrived at the conclusion that concealing the truth would lead to more beneficial consequences for the student than telling the truth, and that this action was in line with the values of humanity and human dignity and thus was just. Since moral decisions are contextual and consequential they cannot be universal or repeat decisions or analogical. On the contrary: the situation always has to be assessed and moral thinking should be applied in order for the right decision to be reached. It is worth pointing out again that Aristotelian practical wisdom and the cultivation of virtues form an important part of the study of the professional ethics of the teacher, and are essential to its meaning.

In the Ethics of Social Consequences, actions and behaviours are assessed on the basis of the consequences and also in relation to the motivation and intention of the agent. In our scenario, the motivation was to act humanly and the intention was to avoid the 
pupil getting hurt because another norm in the ethics of teaching is that the wellbeing (physical, mental and spiritual) of the pupil should be uppermost. The teacher's intention can be assessed as appropriate because her aim was to protect the pupil from physical punishment. The teacher did not do what she did out of fear of the father but because she wanted to avoid an unpleasant, and probably aggressive, confrontation between father and son. Moreover, the teacher was not intentionally unjust. She was justified in her actions which is not the same as justifying it on the basis of the values of the ethics of teaching. The Ethics of Social Consequences is a weak form of non-utilitarian consequentialism that takes a situational approach and is more flexible regarding problem-solving in schools. The teacher decided only to tell the father half the truth regarding John's behaviour because she was trying to avoid his dignity being eroded. She wanted to protect the student from harm and therefore her action can be assessed as right (in the Ethics of Social Consequences this action can only be assessed as being moral if only positive social consequences result from the action).

This teacher possesses certain features of character as well as the ability to think morally and on that basis she did not, under the pressure of the situation, tell the father the whole truth because she wanted to protect her pupil. Her action was humane, protective, compassionate, brave, kind, dignified and virtuous. Her decision contradicted the value, norm, principle or model of good behaviour, in this situation and under these conditions the good of her student took priority over the right action which would have been in line with the rules and norms stated in the code of ethics for instance. I agree with Sandra Cook and David Carr who suggest that virtue preferences may be expressed differently depending on the professional context and situation. For some teachers, the value of justice may be valued more than the value of expressing sympathy towards a vulnerable and helpless child who has behaved badly (Cook \& Carr, 2014, p. 100). In this example, the virtue of protecting and caring for the pupil took priority over justice for the rest of the students in the class. From a professional point of view (pedagogical, social, psychological and managerial), the teacher's action may not be seen as right but the teacher was compassionate, caring, emphatic and these are the desired virtues of teachers' decisions and actions. The teacher could have been motivated to act differently, despite being willing to act on behalf of the student's good. Her decision reflects the appropriacy of the action even though in this situation, it involved risk.

I presume the majority of teachers would have acted in the same way as the teacher in this example because they are motivated to act to protect pupils, i.e. to enhance and promote pupil quality of life in the classroom in line with the values of humanity and human dignity. Teachers should know which actions benefit students and which actions are damaging. I think the action this teacher took can be seen as right and virtuous or as an action taken on the basis of having the character and ability to think morally (and not based upon an absolute ethical norm) which promotes the right decision-making.

\section{Conclusion}

Why are virtues necessary in education? Cook and Carr respond using a differentfrequently repeated-story: At the back of the classroom, two students are talking to each 
other, they are disturbing the others, and are not listening or doing their work. They are disrupting the learning process and distracting the teacher's attention. What should the teacher do? Cook and Carr state that this is not simply about following the institutional (school) norms and principles or achieving educational objectives; there is another dimension as well-how one can promote the moral and material flourishing of all the interested parties in this situation? They suggest the teacher should aim to do more than just make competent and effective decisions, and try to be honest, just, decisive, emphatic and so on as well. However, this not just about good professional practice, but about the virtues required for moral action. They emphasise that the profession of teaching involves flexible and sensitive decision-making in complex and continuously changing conditions, and this may lead to the problem that good teaching is seen only in the context of rules, norms and technical competences. Practical wisdom and thinking are important not only for solving problems in teaching, but also for acting in an honest, just, patient, empathetic and decisive way and in learning self-control. Practical wisdom is related to virtue and the objective of our actions is not only that they should be right (although that is the main aim) but that they should also cultivate a good and virtuous character (Cook \& Carr, 2014, pp. 96-100). This is important because teachers influence others. Carr reminds us that children will be able to follow rules and accept values when taught by teachers who apply them in their everyday teaching and in their private lives. If teachers teach pupils self-control, honesty and integrity then the pupils will cherish these values too. Teachers and their behaviour therefore play a role in the instrumental moral formation of students (Carr, 2006, pp. 177-178).

Based on the example about the father from teaching practice and on the assessment of the action applying the Ethics of Social Consequences, I presume that the teacher's character and adhering to virtues and the ability to think morally in everyday teaching will enable and positive social consequences to prevail over negative ones. These positive consequences certainly include the cultivation of the teacher's character, required in the shaping of pupil morals and to improve pupil quality of life in the classroom, and the teacher's professional and moral decisions and actions influence this. Teachers do not have to follow all the demands regarding virtues ${ }^{8}$, but their actions should always be in accordance with the values of humanity, human dignity and moral right (justice, tolerance and responsibility). The character of the teacher, the role of virtues in the teacher's actions and the ability to think morally and solve problem situations improve the likelihood that the right action will be taken and that positive social consequences will prevail even where some values and virtues relevant to the situation are not upheld, so long the aim is for positive consequences and the good of the student to prevail. Virtues come before consequences, and thus the virtuous teacher should not strive for the best possible consequences and their maximization (as in utilitarian consequentialism). Rather, the teacher should promote and pursue the values and aim to take virtuous action and think morally and the decisions should ensure positive

\footnotetext{
8 A case-oriented approach is not possible in Virtue Ethics. In Virtue Ethics, the teacher should not take actions that conflict with the virtues of the teaching profession. However, this paper does not concern Virtue Ethics, rather I am suggesting that the character (of the teacher) may be another criterion for the evaluation of actions in the Ethics of Social Consequences.
} 
consequences prevail over negative ones, in keeping with non-utilitarian consequentialism and therefore with the Ethics of Social Consequences.

The practice of education gives rise to many situations where taking a contextual and consequentialist approach when making decisions and taking action is primordial, therefore there will be some degree of situatedness and relativism as opposed to universalism or the absolutism of values or the virtues of teaching ethics. But we can agree on certain common, essential ethical and moral values and virtues in the ethics of teaching based on consensus, the social environment of the school, a degree of conformism and even on school policy. Nevertheless the teacher's ability to distinguish between good and bad, right and wrong in specific situations, the ability to think morally, act and argue the point in dialogue with the pupil in different situations is still an essential factor. It is essential we are aware of our responsibility for the consequences of our decisions. Teaching requires flexible and sensitive decisions in contextually changeable professional conditions. This is why courses on the professional ethics of the teacher should be based around the acquisition of ethical knowledge (knowledge of ethical and moral norms, values, rules, teaching virtues, ability to distinguish between what is moral and immoral, right and wrong), improving the future teacher's ability to identify the morally relevant aspects of the situation and to fully understand the morality of the situation. Courses on the professional ethics of the teacher should also promote the ability to think and decide morally so future teachers are able to assess the situation correctly.

Gluchmanová suggests that the Ethics of Social Consequences could be used when seeking solutions to moral problems regarding the ethics of teaching. This theory provides teachers with more options, greater freedom in decision-making and action-taking but it also demands greater responsibility from the teacher compared to, for example, deontology ethics, in which actions should be taken in line with approved or generally accepted rules and the values of that profession (most often expressed in the form of a code of ethics or some other rule) regardless of their applicability to the moral problem or the consequences. Gluchmanová also suggests that thinking and taking decisions and actions in line with values is more difficult than taking action based on other ethical theories because this theory requires people to devote greater effort to thinking about their actions beforehand and evaluating them from various points of view. It also requires them to assess the consequences of alternative actions and take decisions and actions on that basis as well as understand their responsibility for and the consequences of their actions and behaviour (Gluchmanová, 2009a, p. 74).

It is quite difficult to consider a problem from the ethics of teaching perspective and compare one's subjective decisions with the ethical theory and their realization on the basis of the thinking. The Ethics of Social Consequences distinguishes between two types of moral subject - the conformist and the reflexive subject. The complex nature of teaching, its strong ethical dimension and public expectations regarding the teacher's character and actions suggest teachers can be seen as reflexive moral subjects. This implies teachers can differentiate good from bad where pupil quality of life in the classroom is concerned and that they can think morally, which typically requires analytical thinking and reasoning. Teachers should be capable of considering the ethical dimension of teaching, of thinking critically and weighing up the ethical and moral issues, of analysing and proposing solutions, of reflecting 
on their experience so as to identify the positive and negative consequences and thereby strengthen teaching values as a permanent aspect of their character. Teachers should promote values which will help ensure positive consequences prevail over negative ones, bearing in mind the interests and needs of others (pupils). The individual ability of the teacher to aspire to and have the will to make good decisions, to act in accordance with the values of humanity and human dignity, and to promote virtuous actions in everyday teaching is key to ensuring positive social consequences will prevail over negative ones and pupil quality of life in the classroom.

\section{References}

Bilasová, V. (2014). Etická teória a jej význam v etickej výchove [Ethical theory and its importance in ethics education]. In V. Bilasová (Ed.), Etické zošity I. Význam etickej teórie v príprave učitela etickej výchovy [Ethical workbooks I. The importance of ethical theory in training ethics education teachers] (pp. 8-28). Prešov: FF PU.

Bilasová, V. (2016). Etika a etická výchova $\mathrm{v}$ škole [Ethics and ethics education in schools]. In V. Bilasová (Ed.), Filozofia etickej výchovy [Philosophy of ethics education] (pp. 24-25). Prešov: FF PU.

Bilasová, V., \& Žemberová, V. (2005). Z prienikov filozofie, etiky a literatúry (vztahové a interpretačné súvislosti) [Where philosophy, ethics and literature meet (relational and interpretational contexts)]. Prešov: FF PU.

Campbell, E. (2013). The virtuous, wise, and knowledgeable teacher: living the good life as a professional practitioner. Educational Theory, 63(4), 413-429.

Carr, D. (2006). Professional and personal values and virtues in education and teaching. Oxford Review of Education, 32(2), 171-183.

Colnerud, G. (2006). Teacher ethics as a research problem: Syntheses achieved and new issues. Teachers and Teaching: Theory and Practice, 12(3), 365-385.

Cook, S., \& Carr, D. (2014). Virtue, practical wisdom and character in teaching. British Journal of Education Studies, 62(2), 91-110.

Danišková, Z. (2014). What prevents teaching from becoming a profession? Ethics \& Bioethics (in Central Europe), 4(3-4), 191-200.

Gluchman, V. (1997). Človek a morálka [Man and morality]. Brno: Doplněk.

Gluchman, V. (2005). Človek a morálka [Man and morality]. (2 $2^{\text {nd }}$ ed.). Prešov: LIM.

Gluchman, V. (2008). Etika a reflexie morálky [Ethics and reflections on morality]. Prešov: FF PU.

Gluchman, V. (Ed.) (1999). Reflexie o humánnosti a etike [Reflections on humanity and morality]. Prešov: LIM.

Gluchmanová, M., \& Gluchman, V. (2008). Učitelská etika [Teaching ethics]. Prešov: FF PU. Gluchmanová, M. (2009a). Učitelská etika a mravná výchova [Teaching ethics and moral education]. In Š. Ligas, (Ed.), Mravná výchova v školách na Slovensku a v zahraničí. Zborník príspevkov z medzinárodnej vedeckej konferencie [Moral education in schools in Slovakia and abroad. Papers from the International Scientific Conference] (pp. 71-78). Banská Bystrica: PF UMB.

Gluchmanová, M. (2009b): Uplatnenie princípov a hodnôt etiky sociálnych dôsledkov v učitelskej etike [Application of principles and values of ethics of social consequences in teaching ethics]. Prešov: FF PU.

Gluchmanová, M. (2012). Teacher and education versus aggression and violence at school. Ethics \& Bioethics (in Central Europe), 2(1-2), 88-100.Klembarová, J. (2015). Etická výchova ako výchova k hodnotám [Ethics education as education towards values]. In V. Bilasová (Ed.), Etické zošity II. 
Etická výchova v kontexte vzdelávania [Ethical workbooks II. Ethics education in the context of education] (pp. 74-94). Prešov: FF PU.

Klembarová, J. (2012). Do we need professional ethics for special needs education teachers? Ethics \& Bioethics (in Central Europe), 2(3-4), 153-165.

Kuře, J. (2009). Principlism and ar'te: Two methodological approaches in bioethics. In V. Gluchman (Ed.), Bioethics in Central Europe: Methodology and education (pp. 39-56). Prešov: Filozofická fakulta Prešovskej university.

Läänemets, U., Kalamees-Ruubel, K., \& Sepp, A. (2012). What makes a good teacher? Voices of Estonian students. Delta Kappa Gamma Bulletin, 79 (1), 27-31.

Lukášová, H. (2010). Kvalita života dětí a didaktika [A quality of life and didactics]. Praha: Portál.

Lumpkin, A. (2008). Teachers as role models. Teaching character and moral virtues. JOPERD, 78(2), 45-49.

Roffey, S. (2012). Pupil wellbeing - Teacher wellbeing: Two sides of the same coin? Educational \& Child Psychology, 29(4), 8-17.

Seghedin, E. (2014). From the teachers professional ethics to the personal professional responsibility. Acta Didactica Napocensia, 7(4), 13-22.

Žilínek, M. (1997). Étos a utváranie mravnej identity osobnosti [Ethos and shaping a person's moral identity]. Bratislava: Iris.

Institute of Ethics and Bioethics,

University of Prešov,

17. novembra 1 ,

08078 Prešov,

Slovakia

Email: gabriela.platkova-olejarova@unipo.sk 